\title{
Acute Oral and Contact Toxicity of Three Plant Protection Products to Adult Solitary Bees Osmia bicornis
}

\author{
Jaya Sravanthi Mokkapati ${ }^{1 *}$, Agnieszka Wnęk ${ }^{1}$, Ryszard Laskowski ${ }^{1}$, \\ Agnieszka J. Bednarska ${ }^{2}$ \\ ${ }^{1}$ Institute of Environmental Sciences, Jagiellonian University, Gronostajowa 7, 30-387 Kraków, Poland \\ ${ }^{2}$ Institute of Nature Conservation, Polish Academy of Sciences, Mickiewicza 33, 31-120 Kraków, Poland
}

Received: 28 April 2020

Accepted: 16 November 2020

\begin{abstract}
Bee pollinators decline worldwide over the last decades mainly due to the widespread use of pesticides. However, the data on wild bee sensitivity to pesticides are scarce. As it may not be possible to stop using pesticides at the moment due to a growing food demand, we need to make every effort to ensure that they are used in a way that do not jeopardize pollinator populations. We tested the toxicity of three agrochemicals, namely Dursban 480 EC with chlorpyrifos as active ingredient (a.i.), Sherpa 100 EC (a.i. cypermethrin), and Mospilan 20 SP (a.i. acetamiprid), to female Osmia bicornis through oral and contact exposures. The estimated $\mathrm{LC}_{50} \mathrm{~s}$ at infinite-time were lower than concentrations recommended for field application for Dursban in both exposure routes, whereas in case of Sherpa and Mospilan the values were lower for oral exposure only. Regardless of the exposure route, high mortality in less than 24 hours was observed in Dursban-treated bees at a fraction of concentration actually used by farmers in the field, indicating high toxicity of this product to O. bicornis. Therefore, some commonly used insecticides may cause unacceptable effects to pollinators even when applied in the field according to recommendations, indicating the urgent need for revising current pesticide usage regulations.
\end{abstract}

Keywords: insecticides, pollinators, acute toxicity, red mason bee, ecological risk assessment

\section{Introduction}

Bees are the dominant group of insect pollinators globally for several agricultural crops, with crop vulnerability to the loss of pollinators being more than $12 \%$ in regions of Central and Eastern Asia and $11 \%$ in

*e-mail: jayasravanthimokkapati@gmail.com each of Europe and North America [1]. The dramatic decline of bee pollinators in recent decades [1-3], poses a great threat to the food security and ecosystem stability [4] and we must make every effort to stop this trend. Among multiple biotic and abiotic factors leading to pollinator decline, exposure of bees to various pesticides that are applied to crops (via foliar sprays, soil applications or seed treatments) is considered to be a major threat [1-3]. However, in order to meet the growing demand for food, it may be necessary to 
continue to use pesticides at the moment. Therefore, we need to ensure that they are used in an ecologically safer manner that does not cause any threat to pollinator populations.

Among various bee pollinators, solitary bees are important pollinators of many crops, and particularly those of the Osmia genus have been recognized as essential pollinators of several fruit and nut crops, like apples, pears, apricots, oilseed rape and others [5-6]. The red mason bee (Osmia bicornis L.) is one of the most ubiquitous species of solitary bees, widely distributed in Europe, ranging from Scandinavia to the Mediterranean, and occurring also in northern Africa and northern and southwestern Asia [7]. It has particularly been used for pollination of many commercial crops in Europe [5, 8-9], including Poland [10]. Commercial pollination by $O$. bicornis is considered to be advantageous due to the low-cost maintenance, resulting from their morphology and nesting behaviour (i.e. the ease with which bees can be released and retained in a local area) [9], activity even in adverse weather conditions [11], and only a few females being sufficient for pollination of a single flowering fruit tree in contrast to the hundreds of honeybee workers [12]. Despite the recognized ecological and economic importance of solitary bees, they have received much less attention than social bees when it comes to pesticide monitoring and regulation. It has often been reported that the pesticide susceptibility differs among bee species, with some studies indicating that honey bee (Apis mellifera) is more tolerant to insecticides than non-Apis bees [13-14], while few showing that non-Apis bees are less sensitive to insecticides than honey bees [15-16]. The differences between species in sensitivity to insecticides may be explained by the differences in their life-history traits (i.e., body size, sociality, flight season, foraging time, voltinism, floral specialization, nesting behaviour, food consumption rate, overwintering strategies, ratios of pollen and nectar in larval and adult diets), which may result in different ecological impacts from pesticide use [17]. In turn, the contradictory results of some studies comparing honey bees with non-Apis bees may stem from different exposure methods or specific insecticides used. In order to improve our understanding of pesticide sensitivity in non-Apis bees, the European Food Safety Agency (EFSA) suggested including the red mason bee (O. bicornis L.) as solitary bee model organism in the EU pesticide risk assessment scheme [18], yet robust standardised test procedures for acute toxicity in Osmia spp. are still in development. The scarcity of information about the direct or indirect effects of pesticides to O. bicornis limits, thus, its use in risk assessment.

In natural environment, bees have varied food choices at their disposal but in farmland the choice may be significantly limited as the environment is dominated by monocultures, including pollenproducing crops that are sprayed with insecticides. $O$. bicornis bees have been shown to be attracted specifically by oilseed rape cultivations and locate their nesting areas nearby [19], exposing the foraging bees to insecticide residues in nectar and to direct contact with pesticide spray. In addition to different insecticide residues in oilseed rape [20], wild plants (like dandelions) growing near agricultural fields, which are often visited by foraging bees for nectar and pollen, were found to contain neonicotinoid insecticides [21]. In general, different agricultural chemicals have been found in pollen and nectar of crop plants, posing a potential risk to bee pollinators [22-23]. In real-world scenarios, the detrimental effects in bee populations may vary depending on the exposure of foraging bees to pesticides either by direct contact during spraying or by indirect continuous accumulation of pesticide residues in bees via all available contaminated food sources such as nectar and/or pollen [13, 23]. Hence, it is necessary to assess the effects of pesticides on bee species through different routes of exposure, involving both topical treatments and ingestion.

The effects of insecticides to bees could also be different when used as commercially available agrochemical formulations rather than as sole active ingredients typically used in standard bioassays for ecological risk assessment. Formulations usually contain less than $50 \%$ of active ingredients, the rest being surfactants, penetrant enhancers, spreaders, stickers, and/or co-solvents used to optimise the efficacy and stability of the active ingredients [24]. For instance, Chen et al. [25] reported that the toxicity of the neonicotinoid acetamiprid in acute contact laboratory tests on Italian honeybees, Apis mellifera ligustica increased when it was applied topically with the adjuvants (Triton X 100, Silwet L-77, N-methyl pyrrolidone) that are commonly present in different pesticide formulations. Therefore, for better understanding real-world risks from insecticides to populations of $O$. bicornis and other non-target arthropods, it is pivotal to study the toxicity of insecticides applied as actually used agrochemical formulations, preferably through different routes of exposure.

In the present study, we tested three commercially available insecticide agrochemical formulations: Dursban $480 \mathrm{EC}$, an organophosphate containing chlorpyrifos, Sherpa 100 EC, a pyrethroid containing cypermethrin, and Mospilan 20 SP which is a neonicotinoid with acetamiprid as an active ingredient (a.i.), for their toxic effects on adult female $O$. bicornis bees. We conducted laboratory assays exposing the bees to a range of concentrations of individual pesticides by oral and contact topical applications.

\section{Materials and Methods}

\section{Osmia bicornis Emergence and Maintenance}

The experiments were carried out on adult female solitary red mason bee, O. bicornis (previously known 
as Osmia rufa L.) (Hymenoptera: Megachilidae), in the Institute of Environmental Sciences, Jagiellonian University in Kraków, Poland. Only female bees were used in the study because of their sole responsibility for the construction of nest cells and collecting pollen and nectar for future offspring, while the role of males is limited to insemination [26]. Cocoons of O. bicornis were purchased from the local supplier (BioDar, Poland) where the bee colonies were maintained according to the standard commercial technique in the field and cocoons were stored at $4^{\circ} \mathrm{C}$ until use. In March 2018, before each planned experiment, ca. 120 comparatively large cocoons (presumably females) were selected and placed in a cardboard box which was then kept in a big plastic emergence box $(46 \times 30 \times 17 \mathrm{~cm})$ with air flow provision from the top. Adult bees were allowed to emerge from the cocoons by transferring the boxes to the climatic chamber set at $20 \pm 2^{\circ} \mathrm{C}$ temperature, $70 \pm 5 \%$ relative humidity $(\mathrm{RH})$ and $16: 8$ hours light:dark (L:D) regime. Twice a day (morning and evening), male bees, if any, were successively removed from the emergence boxes to minimise fertilization, and female bees were fed ad libitum with sucrose solution.

\section{Insecticides}

Three plant protection products commonly used by farmers in Poland, containing insecticides with different modes of action of active ingredients (a.i.), were taken for the study: Dursban 480 EC (a.i. chlorpyrifos), Sherpa 100 EC (a.i. cypermethrin), and Mospilan 20 SP (a.i. acetamiprid). Table 1 shows the details of the tested agrochemicals together with recommended field application rates (RAR) given by their manufacturers. These RAR values, together with recommended dilutions, were used to calculate Recommended Application Concentrations (RAC) of the agrochemicals to prepare experimental solutions with respect to actual concentrations used by farmers in the field. Toxicity of the insecticides to bees was tested after (1) oral exposure to insecticide-contaminated food and (2) topical application of insecticide solution.

\section{Oral Exposure}

For oral exposure assay, five concentrations of each agrochemical were selected based on a range-finding experiment, and contaminated food was prepared as $33 \%(\mathrm{w} / \mathrm{w})$ sucrose solution using a 4-fold geometric series: $0.00016,0.00063,0.0025,0.01,0.04 \mathrm{RAC}$ for Dursban and $0.04,0.16,0.64,2.56,10.24$ RAC for Sherpa and Mospilan. Insecticide-free sucrose solution served as control treatment. All solutions were stored under the same conditions in which the experiment was carried out to account for possible natural degradation between consecutive feeding sessions, simulating thus real-world situation with a single spray and continuous foraging. Ten bees per treatment were placed in a small plastic box $(18 \times 12 \times 8 \mathrm{~cm})$, with three replicates per treatment. Female bees aged 4-5 days were transferred from emergence boxes to the treatment boxes and starved for 24 hours. On the day of treatment, the movement of bees was slowed down by cooling them at $4^{\circ} \mathrm{C}$ (no longer than $10 \mathrm{~min}$ ) for easy handling. Later, the pre-prepared $2 \mathrm{~mL}$ syringes filled with insecticidecontaminated sucrose solution (or only sucrose for controls) were inserted to assigned treatment boxes from one side (2 syringes per box). In order to attract the bees towards food, the front opening of the syringes, devoid of a conical needle connector, was painted with yellow nail polish and provided with small square-cut yellow sponge-cloth. The treatment boxes were then transferred to the climatic chamber $\left(20 \pm 2^{\circ} \mathrm{C}\right.$, $70 \pm 5 \% \mathrm{RH}, 16: 8 \mathrm{~L}: \mathrm{D})$ and the survival of bees was followed for 7 days by daily observation. The bees were assigned as dead when did not respond to mechanical stimuli. In order to simulate field conditions as closely as possible, the bees were fed ad libitum throughout the experiment by re-filling syringes with their respective sucrose treatment solutions which were kept in the same climatic chamber as back-up feeding solution in falcon tubes.

\section{Topical Application}

Toxicity test procedure for topical application of insecticides on O. bicornis was partially adapted from the OECD test guidelines no. 214 [27] given for the acute contact test for honey bees. The concentrations of insecticide solutions were chosen after the range-finder experiments and were prepared in $0.1 \%$ Triton X-100 (Sigma-Aldrich, Poland) which facilitates the adhesion of applied solution to bees. Four concentrations of Dursban (0.02, 0.08, 0.32, $1.28 \mathrm{RAC}$ ) and five concentrations of Sherpa $(0.0625,0.25,1.0,4.0,16.0$ RAC) and Mospilan (0.1, 0.4, 1.6, 6.4, 25.6 RAC) were used. Triton X-100 at $0.1 \%$ was used as control treatment. On the day of treatment, 10 previously weighed bees were placed in glass Petri dishes of $12 \mathrm{~cm}$ diameter lined with a filter paper $(10$ bees/dish, 3 dishes/treatment) and were anaesthetized at $4^{\circ} \mathrm{C}$ ( $\leq 10 \mathrm{~min}$ ). Using Hamilton syringe with a dispenser, $1 \mu \mathrm{L}$ of an insecticide solution was applied on the pronotum of each bee. The application was started with a control treatment group (only Triton) and continued from the lowest to the highest concentration for each insecticide. Care was taken not to spread the solution on the neck or wing hinges of the bees. The dishes with bees were then transferred to treatment boxes (1 dish per box), giving 3 replicate boxes per treatment, and moved to the climatic chamber $\left(20 \pm 2^{\circ} \mathrm{C}, 70 \pm 5 \%\right.$ RH, 16:8 L:D). Bees in the boxes were fed ad libitum with insecticide-free $33 \% \mathrm{w} / \mathrm{w}$ sucrose solution using inserted syringes and their survival was recorded for 7 days. 


\section{Statistical Analysis}

Statistical analysis was performed using Statgraphics ${ }^{\mathrm{TM}}$ Centurion XVII. For each route of exposure, daily bee survivorships were calculated for each insecticide treatment and corrected using Abott's formula [28]. The values of $\mathrm{LC}_{50}$ (lethal concentration for $50 \%$ of individuals in a toxicity test) were determined for each day using Probit analysis by maximum likelihood method with $95 \%$ confidence limits and expressed as a fraction of RAC (x RAC). Further, $\mathrm{LC}_{50}{ }^{\infty}(\mathrm{x} \mathrm{RAC})$ values, that is ultimate $\mathrm{LC}_{50} \mathrm{~s}$ at time approaching infinity, were calculated using nonlinear regression model with parameters estimated by Marquardt method, assuming an exponential decrease of the $\mathrm{LC}_{50}$ with time [29]:

$$
L C_{50 \infty}=L C_{50}(\mathrm{t})\left(1-e^{-\mathrm{kt}}\right)
$$

...where $t$ is the exposure time after treatment (days), $\mathrm{LC}_{50}(\mathrm{t})$ is the $\mathrm{LC}_{50}$ value at time $t$, and $k$ is the toxic rate constant $\left(\right.$ day $\left.^{-1}\right)$.

To compare our data against those published by other authors for contact tests, the $\mathrm{LC}_{50} \mathrm{~s}$ for topical exposure expressed as $\mathrm{x}$ RAC were recalculated to $\mathrm{LD}_{50} \mathrm{~s}$ - doses of an active ingredient per bee killing $50 \%$ of individuals. This was not possible for oral exposure as the bees were fed ad libitum. Because differences in bee body mass may influence the toxicity when applied topically, the possible differences in body mass between treatment groups were assessed by nested analysis of variance for replicate groups of bees within each tested insecticide concentration.

\section{Results}

The $\mathrm{LC}_{50} \mathrm{~s}$ for all three tested agrochemicals decreased with exposure time both in oral and contact routes of exposure, indicating an increase in toxic effect over time (Table 1). In all cases the ultimate $\mathrm{LC}_{50}{ }^{\infty}$ was reached already after 5-7 days (Fig. 1 and 2). The estimated $\mathrm{LC}_{50}{ }^{\infty} \mathrm{S}$ for all three tested agrochemicals during oral and topical exposure are presented in Table 2.

During oral exposure over 7 days, Dursban showed extremely high toxicity, with $\mathrm{LC}_{50}{ }^{\infty}$ about 250 times lower than the recommended field application concentration (see Table 2). The toxicity was very high already after 24 hours $\left(\mathrm{LC}_{50}=0.012 \mathrm{RAC}\right.$; $95 \%$ CI $0.009-0.018)$ and increased with time, reaching $\mathrm{LC}_{50}=0.004 \mathrm{RAC}(95 \%$ CI $0.002-0.007)$ after 96 hours. The $96 \mathrm{~h} \mathrm{LC}_{50}$ for Dursban was two orders of magnitude lower than $96 \mathrm{~h} \mathrm{CC}_{50} \mathrm{~s}$ for the other two agrochemicals: $0.61 \mathrm{RAC}(95 \%$ CI $0.49-0.80)$ for Sherpa and 0.41 RAC (95\% CI 0.33-0.50) for Mospilan. However, when the corresponding $96 \mathrm{~h} \mathrm{LC}_{50}$ values are expressed as concentrations of active ingredient, chlorpyrifos in Dursban $(0.004 \mathrm{mg}$ a.i. $/ \mathrm{mL})$ is only one

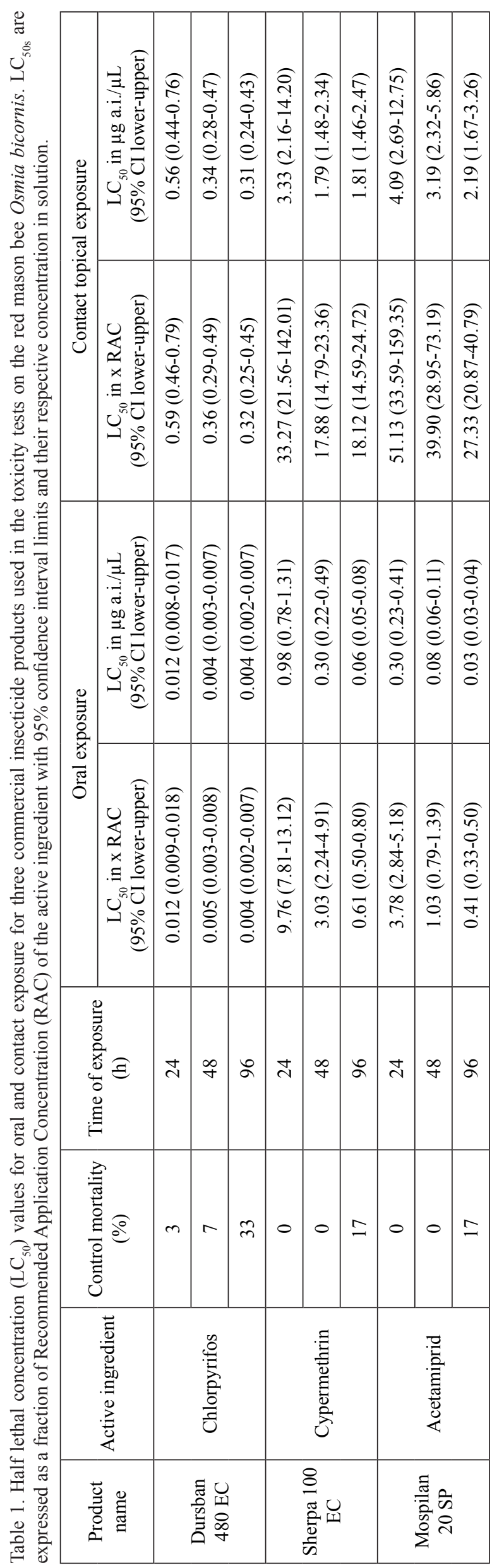




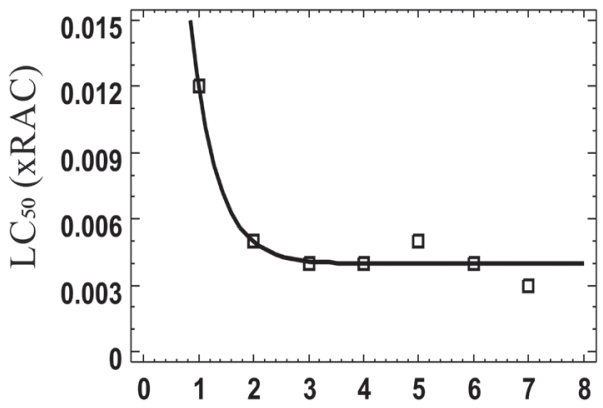

a)

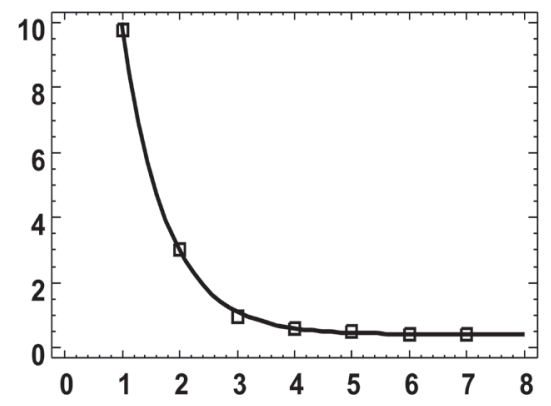

b)

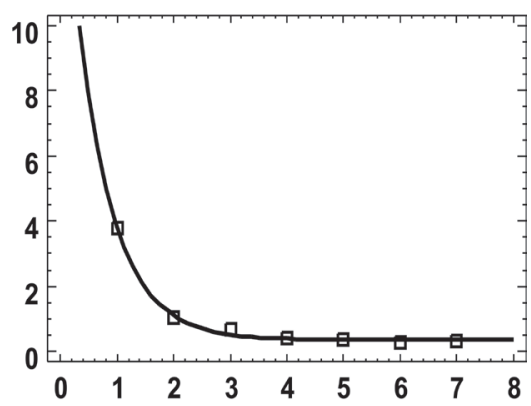

c)

Fig. 1 Toxicity of three insecticides, a) Dursban 480 EC - chlorpyrifos, b) Sherpa 100 EC - cypermethrin and c) Mospilan 20 SP - acetamiprid, to the adult female Osmia bicornis bees through oral route of exposure; RAC - Recommended field Application Concentration of an active ingredient.

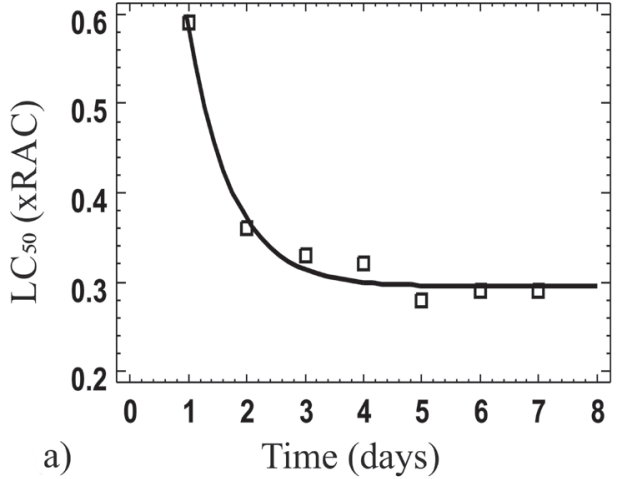

Fig. 2 Toxicity of three insecticides, a) Dursban 480 EC - chlorpyrifos, b) Sherpa 100 EC - cypermethrin and c) Mospilan 20 SP - acetamiprid, to the female adult Osmia bicornis bees through contact topical exposure; RAC - Recommended field Application Concentration of an active ingredient.

order of magnitude more toxic than cypermethrin in Sherpa $(0.061 \mathrm{mg}$ a.i. $/ \mathrm{mL})$ and acetamiprid in Mospilan (0.033 mg a.i. $/ \mathrm{mL})$.

In topical exposure, Dursban again showed the highest toxicity to $O$. bicornis, with $\mathrm{LC}_{50}{ }^{\infty}$ approximately $70 \%$ lower than the concentration recommended for field application for this product (Table 1). The estimated $48 \mathrm{~h} \mathrm{LD}_{50}$ was $0.34 \mu \mathrm{g} /$ bee $(95 \% \mathrm{CI}$ 0.28-0.47) for chlorpyrifos in Dursban, while the values were $1.79 \mu \mathrm{g} / \mathrm{bee}(95 \%$ CI $1.48-2.34)$ and $3.19 \mu \mathrm{g} / \mathrm{bee} \quad(95 \%$ CI $2.37-5.85)$ respectively for cypermethrin in Sherpa and acetamiprid in Mospilan. Analysis of variance did not detect any differences in bee body mass among treatment groups $(p=0.95$, Nested ANOVA for replicate bee groups within treatments).

\section{Discussion}

In this study, the plant protection products were used in real-world-realistic conditions, i.e., by exposing female bees to agrochemical formulations that are actually used by farmers rather than only to active ingredients. As stressed by Benuszak et al. [30], tests on commercial formulations should not be restricted to the regulatory context. The authors found that from among ca. 50 different pesticides studied in scientific experimentations on honey bees, agrochemical formulations were used in less than $50 \%$ of the scientific articles [30]. In order to best simulate field conditions, in the oral exposure the bees were allowed to feed ad libitum as presumably they would indeed do in the field, and in the contact test the bees were exposed topically to a single droplet of a pesticide solution, simulating direct overspray of bees foraging in highly bee-attractive crops. Moreover, in the oral exposure test, natural degradation of the insecticides was allowed, simulating thus the real-world situation for foraging bees. In natural conditions, bees forage continuously throughout the days following pesticide application and insecticides applied to crops are subject to degradation. This natural degradation of insecticide residues can be attributed to many physicochemical factors including photolysis, abiotic chemical degradation, biotic metabolization, volatilization and dilution during plant growth [31], and in particular, the half-life for most modern insecticides $\left(\mathrm{DT}_{50}\right.$ : time required for $50 \%$ degradation of residues) 


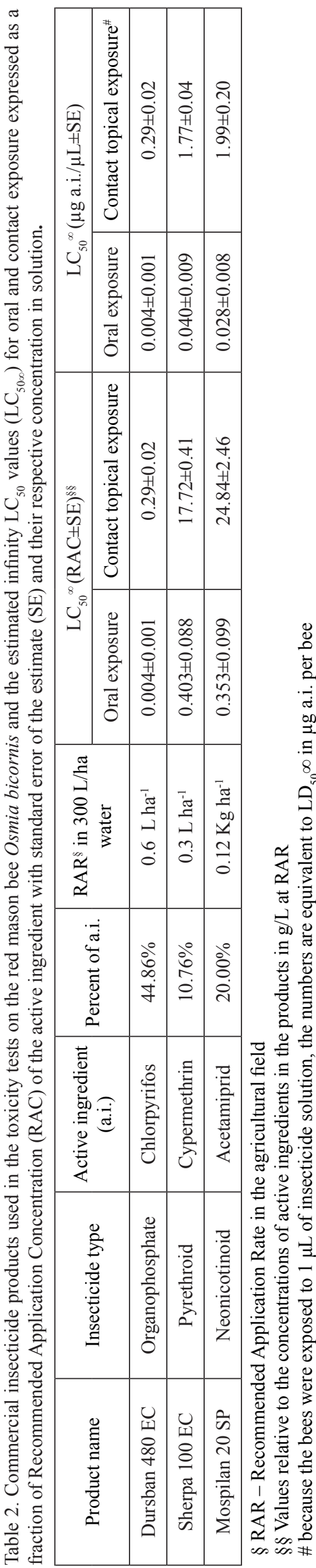

is assumed to be 10 days from first order kinetics [18]. Hence, while bees continue feeding on contaminated nectar, after few days since application it may contain only minimal amounts of pesticide residues and/or their metabolites [32]. Irrespectively of that, the $\mathrm{LC}_{50}$ values in our study are expressed with respect to concentrations recommended for field application (RAC), i.e. potential initial concentrations in food, giving thus an insight into toxicity of plant protection products as they are actually used in the field. We believe, thus, that our experiment well represents actual exposure of solitary bees to plant protection products and their actual field toxicity to the bees. So far, toxicity data for the tested insecticides (i.e. chlorpyrifos, cypermethrin and acetamiprid) through direct oral exposure, either as pure active substance or in formulated products, are very scarce in solitary bees, perhaps in some Osmia species like $O$. cornifrons for acetamiprid by Biddinger et al. [33], but conceivably none in $O$. bicornis. Hence, results of the oral tests presented herein could be compared to those reported for other bee species.

High chlorpyrifos (in Dursban 480 EC) toxicity through oral exposure has previously been reported for honey bees, with $0.33 \mu \mathrm{g}$ a.i./bee $\mathrm{LD}_{50}$ for $48 \mathrm{~h}$ [34]. Yet, the toxicity studies on non-Apis bees are still limited, especially on solitary bees. It was observed elsewhere that the consumption of 33\% sugar solution in newly emerged $O$. bicornis females under laboratory conditions ranged between 31.7-104.2 $\mu \mathrm{L} /$ day with an average of $59.8 \mu \mathrm{L} /$ day [35]. Assuming this average consumption rate, the $\mathrm{LD}_{50 \mathrm{~s}}$ in our studies for the first $24 \mathrm{~h}$ of continuous oral exposure in $O$. bicornis were estimated as $0.72 \mu \mathrm{g}$ a.i./bee for chlorpyrifos in Dursban, $58.4 \mu \mathrm{g}$ a.i./bee for cypermethrin in Sherpa and $18.1 \mu \mathrm{g}$ a.i./bee for acetamiprid in Mospilan. In addition, adult Osmia females are known to ingest also pollen, although no data on its consumption rate are available [36]. This means that the cumulative effects of pesticides consumed with both pollen and nectar have yet to be observed in solitary bees.

The extreme toxicity of Dursban to $O$. bicornis was confirmed in topical exposure test. Recently, Uhl et al. [16] tested the sensitivities of bees to different commercial insecticide formulations via topical contact exposure and observed that $O$. bicornis was more resistant than $A$. mellifera, consequently questioning $O$. bicornis use as a surrogate model organism to honey bees in pesticide risk assessment. The reported $48 \mathrm{~h} \mathrm{LD}_{50 \mathrm{~s}}$ for $O$. bicornis and A. mellifera respectively were: 4.19 (95\% CI 2.91-5.46) and $3.19 \mu \mathrm{g} / \mathrm{bee}$ for chlorpyrifos in Pyrinex ${ }^{\circledR}, 0.24 \quad(95 \%$ CI $0.16-0.33)$ and $0.09 \mu \mathrm{g} /$ bee for $\alpha$-cypermethrin in Fastac ${ }^{\circledR}$ SC and $1.72(95 \%$ CI $0.85-2.59)$ and $9.26 \mu \mathrm{g} / \mathrm{bee}$ for acetamiprid in Mospilan ${ }^{\circledR}$ SG [16]. Interestingly, chlorpyrifos in Dursban showed one order of magnitude higher toxicity to $O$. bicornis $\left(48 \mathrm{~h} \mathrm{LD}_{50} 0.34 \mu \mathrm{g}\right.$ a.i./bee) than it was found in Pyrinex (4.19 $\mu$ g a.i./bee) and cypermethrin in Sherpa $\left(48 \mathrm{~h} \mathrm{LD}_{50} 1.79 \mu \mathrm{g}\right.$ a.i./bee) showed a lower toxicity than $\alpha$-cypermethrin in Fastac 
(0.24 $\mu \mathrm{g}$ a.i./bee) [16]. Although cypermethrin and $\alpha$-cypermethrin are two different active ingredients, the differences in toxicity between them seem to be small, at least in acute contact test on A. mellifera with the $24 \mathrm{~h}$ $\mathrm{LD}_{50}$ being $0.02 \mu \mathrm{g}$ a.i./bee for cypermethrin and 0.03 $\mu \mathrm{g}$ a.i./bee for $\alpha$-cypermethrin [13].

Differences in toxicity among different agrochemical formulations based on the same active ingredient can perhaps be explained by the fact that other ingredients (all chemicals other than the active ingredient) used in commercial formulations, even if non-toxic by their own, may interact with active ingredients increasing their toxicity. These added adjuvants/co-formulants include surfactants, penetrant enhancers, activators, spreaders, stickers, wetting agents, buffers, antifoaming agents, drift retardants, etc., and are being used to facilitate tank-mixing and achieve high efficacy of pesticides for the targeted pests, potentiating the toxicity of active insecticide ingredients by enhancing their penetration ability through insect skin/cuticle and systemic movement across the tissues or cells inside the body [24]. The rather minor discrepancy between the $48 \mathrm{~h} \mathrm{LD}_{50} \mathrm{~s}$ for $O$. bicornis found in our study and study by Uhl et al. [16] (i.e., 3.2 vs. $1.72 \mu \mathrm{g}$ a.i./bee) for acetamiprid may be due to slight experimental differences in treatments, i.e., 1 vs. $2 \mu \mathrm{L}$ topical application per bee, the use of $0.1 \%$ vs $0.5 \%$ wetting agent and different physical form of the Mospilan products used: Uhl et al. [16] used soluble granules, whereas it was in powder form in our study.

Although the organophosphate insecticide chlorpyrifos is one of the most commonly used chemicals controlling the majority of pests of economic importance in a range of crops [37], our study revealed that at least some chlorpyrifos-based agrochemicals, namely Dursban, can cause unacceptable effects in solitary bee populations. As a good replacement for organophosphates, pyrethroid insecticides are recommended due to their broad spectrum of action and relatively low doses of application [38] and are currently used on a large scale mainly in fruit orchards [39]. However, high toxicity of cypermethrin to many organisms, including honeybees and other non-target invertebrates, have been widely reported [39-40]. Moreover, in accordance with cypermethrin mechanism of action, i.e. blocking sodium channels in the nervous system leading to paralysis [41], such effects were also noticed in our experiments. During daily observations of bee survival, it was seen that many individuals had problems with walking, flying or being overturned before dying (considered as moribund but not counted as dead). Similar effects were observed in other studies - for example, A. mellifera, fed with food containing pyrethroids spent more time turned upside down and had problems with recovery [39].

Mospilan, containing acetamiprid which belongs to systemic neonicotinoids, is another plant protection product widely used to control pests in various agricultural crops [42]. Although in oral application the estimated $\mathrm{LC}_{50}{ }^{\infty}$ was below the concentration recommended for field application (0.353 RAC), in topical treatment test it appeared the least toxic insecticide among those tested in our study, with $\mathrm{LC}_{50}{ }^{\infty}$ almost 25 times higher than RAC. The relatively low toxicity of acetamiprid in contact exposure can further be supported by the studies on another species of the Osmia genus, O. corniforis, for which the $48 \mathrm{~h} \mathrm{LD}_{50}$ was $4.0 \mu \mathrm{g}$ a.i./bee using Assail $30 \mathrm{SG}$ [33], and also for A. mellifera with $24 \mathrm{~h}$ LD $_{50} 1.69 \mu \mathrm{g}$ a.i./bee using Mospilan 20 SP [43] and $7.07 \mu \mathrm{g} /$ bee using technical grade acetamiprid [44]. The underlying rapid metabolism of acetamiprid in vivo could be the contributing factor for its relatively low toxicity in bees [45].

The $\mathrm{LC}_{50}{ }^{\infty}$ values (sometimes regarded as threshold lethal concentration) can be helpful in determining toxicity after prolonged exposure of an organism to a toxicant. In case of O. bicornis, in our studies the estimated $\mathrm{LC}_{50}{ }^{\infty} \mathrm{S}$ confirmed the order of toxicity regardless of the exposure route as: Dursban $>>$ Sherpa $\geq$ Mospilan. As the $\mathrm{LC}_{50}{ }^{\infty}$ eliminates the problem of different exposure times used in different tests, toxicity expressed in such a way can be used to determine the overall effects on populations when combined with field observations [46].

\section{Conclusions}

The study clearly showed that at least some commercial insecticide formulations may cause unacceptable effects to important bee pollinators such as $O$. bicornis even when used according to the recommended field application, indicating the urgent need for revising current pesticide regulations. It is worth noting that the most toxic among the tested insecticides, representing three major groups: organophosphates, pyrethroids and neonicotinoids, was the broad spectrum and commonly used Dursban 480 EC with chlorpyrifos as an active ingredient. The least toxic appeared Mospilan 20 SP containing the neonicotinoid acetamiprid. These results bring new light into the discussion on the use of neonicotinoids and their replacements for pest control. Although acetamiprid has been approved by the European Commission [47], the total ban on neonicotinoids is still being discussed. As long as we have to use insecticides, the discussion should take into account possible sideeffects of such a ban, in the first place the replacement with other insecticides which, as proven in our study, may appear even more dangerous to bees. These findings reinforce the notion that solitary bees are the pollinating group at high risk from pesticide toxicity. With the importance of pollinators safety and diversity to the high productivity of several crops, further studies on the influence of insecticides and the vulnerability of different bee species are sorely needed. We argue that tests should be performed on commercially used 
formulations to account for possible interactions between active ingredients and other components of the formulations, and the length of the test should allow for estimating $\mathrm{LC}_{50}{ }^{\infty}$ and/or $\mathrm{LD}_{50}{ }^{\infty}$. For risk assessment, we also recommend that the test results should be reported also in respect to recommended field application concentrations (RAC) and rates (RAR).

\section{Acknowledgements}

This study was financially supported by National Science Centre, Poland (Grant no: 2015/19/B/ NZ8/01939). The authors thank Jagiellonian University in Kraków, Poland, for providing infrastructure facilities under DS funding scheme (Grant no: DS/ WBiNoZ/INoS/756/2018).

\section{Conflict of Interest}

The authors declare no conflict of interest.

\section{References}

1. POTTS S.G., BIESMEIJER J.C., KREMEN C., NEUMANN P., SCHWEIGER O., KUNIN W.E. Global pollinator declines: Trends, impacts and drivers. Trends Ecol. Evol. 25 (6), 345, 2010.

2. MIGDAE P., ROMAN A., POPIELA-PLEBAN E., KOWALSKA-GÓRALSKA M., OPALIŃSKI S. The impact of selected pesticides on honey bees. Pol. J. Environ. Stud. 27 (2), 787, 2018.

3. BIESMEIJER J.C., ROBERTS S.P., REEMER M., OHLEMÜLLER R., EDWARDS M., PEETERS T., SCHAFFERS A.P., POTTS S.G., KLEUKERS R., THOMAS C.D., SETTELE J. Parallel declines in pollinators and insect-pollinated plants in Britain and the Netherlands. Science. 313 (5785), 351, 2006.

4. GILL R.J., RAMOS-RODRIGUEZ O., RAINE N.E. Combined pesticide exposure severely affects individualand colony-level traits in bees. Europe PMC Funders Group. 491 (7422), 105, 2013.

5. BLITZER E.J., GIBBS J., PARK M.G., DANFORTH B.N. Pollination services for apple are dependent on diverse wild bee communities. Agric. Ecosyst. Environ. 221, 1, 2016.

6. FELICIOLI A., PINZAUTI M. Pollination by Osmia bees (Hymenoptera: Megachilidae)., In: CAPINERA J.L., (ed), Encyclopaedia of Entomology Springer: Netherlands, Volume 1, 2971, 2008.

7. LHOMME P. Osmia bicornis. The IUCN Red List of Threatened Species, e.T19198431A21154926, 2014. https:// ec.europa.eu/environment/nature/conservation/species/ redlist/downloads/European bees.pdf

8. RYDER J.T., CHERRILL ${ }^{-}$A., PREW R., SHAW J., THORBEK P., WALTERS K.F. Impact of enhanced Osmia bicornis (Hymenoptera: Megachilidae) populations on pollination and fruit quality in commercial sweet cherry (Prunus avium L.) orchards. J. Apic. Res. 59 (1), 77, 2020.

9. HANSTED L., GROUT B.W., TOLDAM-ANDERSEN T.B., EILENBERG J. An assessment of Osmia rufa (syn. bicornis) as a pollinator of the sour cherry (Prunus cerasus) cv. stevnsbaer in Eastern Denmark. J. Apic. Res. 53 (1), 177, 2014.

10. BILIŃSKI M., TEPER D. Rearing and utilization of the red mason bee - Osmia rufa L. (Hymenoptera, Megachilidae) for orchard pollination. J. Apic. Sci. 48 (2), 69, 2004.

11. GULER Y., DIKMEN F. Potential bee pollinators of sweet cherry in inclement weather conditions. J. Entomol. Res. Soc. 15 (3), 9, 2013.

12. KRUNIĆ M., STANISAVLJEVIĆ L. Augmentation of managed populations of Osmia cornuta and O. rufa (Hymenoptera: Megachilidae) in Southeastern Europe. European J. Entomol. 103 (3), 695, 2006.

13. ARENA M., SGOLASTRA F. A meta-analysis comparing the sensitivity of bees to pesticides. Ecotoxicol. 23 (3), 324, 2014.

14. HEARD M.S., BAAS J., DORNE J.L., LAHIVE E., ROBINSON A.G., RORTAIS A., SPURGEON D.J., SVENDSEN C., HESKETH H. Comparative toxicity of pesticides and environmental contaminants in bees: Are honey bees a useful proxy for wild bee species? Sci. Total Environ., 578, 357, 2017.

15. THOMPSON H.M., PAMMINGER T. Are honeybees suitable surrogates for use in pesticide risk assessment for non-Apis bees? Pest Manag. Sci. 75 (10), 2549, 2019.

16. UHL P., AWANBOR O., SCHULZ R.S., BRÜHL C.A. Is Osmia bicornis an adequate regulatory surrogate? Comparing its acute contact sensitivity to Apis mellifera. PloS One. 14 (8), e0201081, 2019.

17. BRITTAIN C., POTTS S.G. The potential impacts of insecticides on the life-history traits of bees and the consequences for pollination. Basic Appl. Eco. 12 (4), 321, 2011.

18. EFSA, European Food Safety Authorization. Guidance on the risk assessment of plant protection products on bees (Apis mellifera, Bombus spp. and solitary bees). EFSA J. 11, 3295, 2013.

19. HOLZSCHUH A., DORMANN C.F., TSCHARNTKE T., STEFFAN-DEWENTER I. Mass-flowering crops enhance wild bee abundance. Oecologia. 172 (2), 477, 2013.

20. PIHLSTRÖM T., ISAAC G., WALDEBÄCK M., ÖSTERDAHL B.G., MARKIDES K.E. Pressurised fluid extraction (PFE) as an alternative general method for the determination of pesticide residues in rape seed. Analyst. 127 (4), 554, 2002.

21. KRUPKE C.H., HUNT G.J., EITZER B.D., ANDINO G., GIVEN K. Multiple routes of pesticide exposure for honey bees living near agricultural fields. PLoS One. 7 (1), e29268, 2012

22. PIECHOWICZ B., GRODZICKI P., PODBIELSKA M., TYRKA N., ŚLIWA M. Transfer of active ingredients from plant protection products to a honeybee (Apis mellifera $f$.) hive from winter oilseed rape crops protected with conventional methods. Pol. J. Environ. Stud. 27 (3), 1219, 2018.

23. SANCHEZ-BAYO,F., GOKA K. Pesticide residues and bees - A risk assessment. PLoS One, 9 (4), e94482, 2014.

24. MULLIN C.A., CHEN J., FINE J.D., FRAZIER M.T., FRAZIER J.L. The formulation makes the honey bee poison. Pestic. Biochem. Physiol. 120, 27, 2015.

25. CHEN L., YAN Q., ZHANG J., YUAN S., LIU X. Joint toxicity of acetamiprid and co-applied pesticide adjuvants on honeybees under semifield and laboratory conditions. Environ. Toxicol. Chem. 38 (9), 1940, 2019.

26. RAW A. The biology of the solitary bee Osmia rufa (L.) (Megachilidae). Trans. R. Ent. Soc. Lond. 124 (3), 213, 1972. 
27. OECD, Organisation for Economic Cooperation and Development., Guideline for the testing of chemicals, no. 214 honeybees: acute contact toxicity test; Paris, 1998.

28. ABBOTT W.S. A method of computing the effectiveness of an insecticide. J. Econ. Entomol. 18 (2), 265, 1925.

29. CROMMENTUIJN T., DOODEMAN C.J.A.M., DOORNEKAMP A., VAN DER POL J.J. VAN GESTEL C.A.M., BEDAUX J.J. Lethal body concentrations and accumulation patterns determine time-dependent toxicity of cadmium in soil arthropods. Environ. Toxicol. Chem. 13 (11), 1781, 1994.

30. BENUSZAK J., LAURENT M., CHAUZAT M.P. The exposure of honey bees (Apis mellifera; Hymenoptera: Apidae) to pesticides: Room for improvement in research. Sci. Total Environ. 587, 423, 2017.

31. WILLIS G.H., MCDOWELL L.L. Pesticide persistence on foliage. In Reviews of environmental contamination and toxicology, Springer: New York, Volume 100, 23, 1987.

32. BONMATIN J.M., GIORIO C., GIROLAMI V., GOULSON D., KREUTZWEISER D.P., KRUPKE C., LIESS M., LONG E., MARZARO M., MITCHELL E.A., NOOME D.A. Environmental fate and exposure; neonicotinoids and fipronil. Environ. Sci. Pollut. Res. 22 (1), 35, 2015.

33. BIDDINGER D.J., ROBERTSON J.L., MULLIN C., FRAZIER J., ASHCRAFT S.A., RAJOTTE E.G., JOSHI N.K., VAUGHN M. Comparative toxicities and synergism of apple orchard pesticides to Apis mellifera (L.) and Osmia cornifrons (Radoszkowski). PLoS ONE. 8 (9), e72587, 2013.

34. GIESY J.P., SOLOMON K.R., CUTLER G.C., GIDDINGS J.M., MACKAY D., MOORE D.R., PURDY J., WILLIAMS W.M. Ecological risk assessment of the uses of the organophosphorus insecticide chlorpyrifos in the United States. In Giesy J., Solomon K., (eds) Ecological risk assessment for chlorpyrifos in terrestrial and aquatic systems in the United States, Springer: USA, Volume 231, pp. 1, 2014.

35. SGOLASTRA F., HINAREJOS S., PITTS-SINGER T.L., BOYLE N.K., JOSEPH T., LŪCKMANN J., RAINE N.E., SINGH R., WILLIAMS N.M., BOSCH J. Pesticide exposure assessment paradigm for solitary bees. Environ. Entomol. 48 (1), 22, 2019.

36. CANE J.H., DOBSON H.E.M., BOYER B. Timing and size of daily pollen meals eaten by adult females of a solitary bee (Nomia melanderi) (Apiformes: Halictidae). Apidolog. 48 (1), 17, 2017.
37. GIDDINGS J.M., WILLIAMS M.W., SOLOMON K.R., GIESY J.P. Risks to aquatic organisms from use of chlorpyrifos in the United States. In Ecological risk assessment for chlorpyrifos in terrestrial and aquatic systems in the United States, Springer: USA, 119, 2014.

38. OROS,D.R., WERNER,I. Pyrethroid insecticides: an analysis of use patterns, distributions, potential toxicity and fate in the Sacramento-San Joaquin delta and Central Valley., White paper for the interagency ecological program. SFEI contribution 415; San Francisco Estuary Institute, Oakland, CA, 2005.

39. OLIVER C.J., SOFTLEY S., WILLIAMSON S.M., STEVENSON P.C., WRIGHT G.A. Pyrethroids and nectar toxins have subtle effects on the motor function, grooming and wing fanning behaviour of honeybees (Apis mellifera). PLoS One. 10 (8), e0133733, 2015.

40. PASHTE V.V., PATIL C.S. Toxicity and poisoning symptoms of selected insecticides to honey bees (Apis mellifera mellifera L.). Arch. Biol. Sci. 70 (1), 5, 2018.

41. CASIDA J.E., DURKIN K.A. Neuroactive insecticides: targets, selectivity, resistance, and secondary effects. Annu. Rev. Entomol. 58 (1), 99, 2013.

42. KURWADKAR S., EVANS A. Neonicotinoids: systemic insecticides and systematic failure. Bull. Environ. Contam. Toxicol. 97 (6), 745, 2016.

43. BADAWY M.E.I., NASR H.M., RABEA E.I. Toxicity and biochemical changes in the honey bee Apis mellifera exposed to four insecticides under laboratory conditions. Apidolog. 46 (2), 177, 2015.

44. IWASA T., MOTOYAMA N., AMBROSE J.T., ROE R.M. Mechanism for the differential toxicity of neonicotinoid insecticides in the honey bee, Apis mellifera. Crop Prot. $\mathbf{2 3}$ (5), 371, 2004.

45. MANJON C., TROCZKA B.J., ZAWORRA M., BEADLE K., RANDALL E., HERTLEIN G., SINGH K.S., ZIMMER C.T., HOMEM R.A., LUEKE B., REID R. Unravelling the molecular determinants of bee sensitivity to neonicotinoid insecticides. Curr. Biol. 28 (7), 1137, 2018.

46. ASHAUER R., BOXALL A., BROWN C. Predicting effects on aquatic organisms from fluctuating or pulsed exposure to pesticides. Environ. Toxicol. Chem. 25 (7), 1899, 2006.

47. EUROPEAN COMMISSION. Commission implementing regulation (EU) 2018/113. Official J. European Union: L 20/7 - L20/10, 2018. 